\title{
Mammogenesis and Induced Lactation With or Without Reserpine in Nulliparous Dairy Goats
}

\author{
A. A. K. Salama, ${ }^{*}{ }^{1}$ G. Caja, ${ }^{*}$ E. Albanell, ${ }^{*}$ S. Carné,${ }^{*}$ R. Casals, ${ }^{*}$ and X. Such ${ }^{\star}$ \\ ${ }^{*}$ Grup de Recerca en Remugants, Departament de Ciència Animal i dels Aliments, Universitat Autònoma de Barcelona, Bellaterra, Spain \\ †Sheep and Goat Research Department, Animal Production Research Institute, 12311 Dokki, Giza, Egypt
}

\begin{abstract}
Nulliparous goats were used to evaluate the effects of a standard protocol for inducing lactation with or without using a prolactin-releasing agent (reserpine). Estrus was synchronized and goats were submitted to daily s.c. injections of estradiol- $17 \beta$ and progesterone ( 0.5 and $1.25 \mathrm{mg} / \mathrm{kg}$ of body weight, respectively) for 7 $\mathrm{d}$. The goats were divided into 2 groups and injected i.m. with $1 \mathrm{mg} / \mathrm{d}$ of reserpine $(\mathrm{n}=7)$ or the vehicle $(\mathrm{n}=$ 7 ) on $\mathrm{d} 12,14,16,18$, and 20 . Lactation was initiated by i.m. injections of dexamethasone $(10 \mathrm{mg} / \mathrm{d})$ from $\mathrm{d}$ 18 to 20. Goats were machine milked once daily from d 21 to 120 , at which time they were mated with herd sires. Milk was measured and sampled daily during wk 1 of lactation and weekly thereafter. Udder traits were measured in all goats at $d-2$ (before the induction treatment) and on d 35 and 100 (during lactation). Goats initiated lactation on d 21 (100\%) and milk yield increased thereafter. The milk yield of control and reserpine-treated goats increased as lactation advanced, peaking at wk 10 of lactation, when reserpine-treated goats yielded $1,079 \pm 89 \mathrm{~mL} / \mathrm{d}$ of milk compared with $850 \pm 96 \mathrm{~mL} / \mathrm{d}$ for control goats. Yet milk yield at the peak was only $55 \%$ of the peak milk yield observed in contemporary primiparous goats. The composition of initial milk (d 21) was different from that expected for colostrum. Milk composition stabilized after $\mathrm{d} 3$ of lactation. There were no differences among groups for milk fat, protein, casein, or whey protein, but milk from control goats contained greater nonprotein nitrogen than that from reserpine-treated goats $(0.48 \pm 0.02$ vs. 0.41 $\pm 0.02 \%)$. Teat length increased from $24.7 \pm 1.1$ to 34.5 $\pm 2.4 \mathrm{~mm}$ in control goats during mammogenesis $(\mathrm{d}-2$ to 35$)$, but stabilized in reserpine goats $(25.2 \pm 2.2 \mathrm{~mm})$. The distance between teats $(11.5 \pm 0.4 \mathrm{~cm})$, and the volume $(922 \pm 63 \mathrm{~mL})$ and depth $(15.6 \pm 0.60 \mathrm{~cm})$ of the udder increased similarly in both groups during
\end{abstract}

Received January 19, 2007.

Accepted April 17, 2007.

${ }^{1}$ Corresponding author: ahmed.salama@uab.es mammogenesis and lactation. After mating, $82 \%$ of herdmates became pregnant, whereas only $21 \%$ of the lactation-induced goats conceived (1 reserpine-treated and 2 control goats). In conclusion, lactation induction was effective in nulliparous goats, but neither milk yield nor the side effects on fertility seem to support its recommendation.

Key words: lactation induction, prolactin, milk composition, dairy goat

\section{INTRODUCTION}

Smith and Schanbacher (1973) proposed a protocol in which lactation was induced in dairy cows by a 7-d estradiol and progesterone treatment. Compared with the lactation occurring during pregnancy, mammary growth during lactation induction is considered insufficient and varies widely among animals. Therefore, lactation induction has had a variable success rate (58 to $80 \%$ ) and has resulted in variable milk yield (50 to $106 \%$ of natural lactation) in cows (Smith and Schanbacher, 1973; Collier et al., 1975) and ewes (Head et al., 1980). Researchers have tried to improve the consistency of response among lactation-induced cows and ewes by including corticoids (Chakriyarat et al., 1978; Head et al., 1980), reserpine (RES; Collier et al., 1977; Kensinger et al., 1979), placental lactogen (Byatt et al., 1997), somatotropin (Kann, 1997), or prostaglandin (Lukas et al., 2003).

Lactation induction has received little attention in dairy goats compared with dairy cows and ewes. The first attempts to induce lactation in dairy goats (Cowie et al., 1965; Hart and Morant, 1980) used long-time steroid priming (35 to $140 \mathrm{~d}$ ), which is unpractical and may be uneconomical. Fowler et al. (1991) used estrogen and progesterone for $11 \mathrm{~d}$, followed by dexamethasone for $3 \mathrm{~d}$ and RES during the last $5 \mathrm{~d}$. Their experiment had no controls that had not been treated with RES. Chilliard et al. (1986) used the method of Smith and Schanbacher (1973), with a 7-d lactation-induction treatment, in dairy goats, which yielded $55 \%$ of the milk produced by naturally lactating goats. To our knowl- 
edge, no studies have compared the effects of improved protocols of induced lactation in dairy goats.

Hart and Morant (1980) concluded that increased levels of plasma prolactin (PRL) are essential for a successful induction of mammary growth and lactation in dairy goats. No increase in udder size was observed when PRL was maintained at basal concentrations by injecting bromocriptine, a PRL inhibitor. Moreover, increasing the dose of estrogens and decreasing that of progesterone led to an increase in both plasma PRL and udder size and stimulated the onset of lactation.

In the present study we included RES, a PRL-releasing agent, in the induction protocol. Reserpine blocks the inhibitory effects of dopamine on the pituitary cells that secrete PRL (lactotrophs) by binding to dopamine receptors. Collier et al. (1977) and Kensinger et al. (1979) injected dairy cows with RES from d 2 to 14 or 16 of the treatment. The PRL levels were low during the 7-d steroid injection because of the inhibitory effect of progesterone on PRL secretion, but increased from d 14 to 17 of the treatment and then decreased (Erb et al., 1976; Kann, 1997). Nonetheless, levels of PRL during pregnancy are high for a few days before kidding (Davis et al., 1979). Therefore, we hypothesized that it may be convenient to extend the injections of RES until d 20 of the treatment ( $1 \mathrm{~d}$ before milking) to better simulate the natural hormonal milieu at kidding. The objective of this study was to evaluate changes in milk yield, milk composition, and udder morphology in nulliparous dairy goats induced to lactate with or without RES treatment.

\section{MATERIALS AND METHODS}

The experimental procedures and animal care conditions were approved by the Ethical Committee on Animal and Human Experimentation of the Universitat Autonoma de Barcelona.

\section{Animals, Treatments, and Management Conditions}

A total of 14 nulliparous Murciano-Granadina goats $(17.3 \pm 0.1 \mathrm{mo}$ of age and $37.5 \pm 1.0 \mathrm{~kg}$ of BW) from the herd of the Servei de Granges i Camps Experimentals, Universitat Autonoma de Barcelona, were allocated to 2 balanced experimental groups. To eliminate the possible effect of the reproductive state on the response to hormones used to induce lactation, estrus was synchronized (February 1) using 40-mg fluoroprogesterone vaginal sponges (Chronolone, Intervet, Salamanca, Spain) for $14 \mathrm{~d}$ prior to initiating the lactation induction scheme. Pregnant mare serum gonadotrophin (300 IU; Intervet) was injected i.m. at the time of sponge withdrawal.
Induction of lactation started $7 \mathrm{~d}$ after sponge withdrawal, and all goats received daily s.c. injections of estradiol- $17 \beta(0.5 \mathrm{mg} / \mathrm{kg}$ of BW) and progesterone (1.25 $\mathrm{mg} / \mathrm{kg}$ of BW) in 2 portions at 0800 and $1800 \mathrm{~h}$ on d 1 to 7. Goats were injected i.m. with $1 \mathrm{mg} / \mathrm{d}$ of RES ( $\mathrm{n}=$ $7)$ or the vehicle as a control $(\mathrm{n}=7)$ at $0900 \mathrm{~h}$ on $\mathrm{d} 12$, 14, 16, 18, and 20. Eight goats came from 4 sets of twins and were assigned to either the control or RES group, balanced according to BW and milk yield of mothers. Lactation in all goats was initiated by dexamethasone $(10 \mathrm{mg} / \mathrm{d})$ injected s.c. at $0900 \mathrm{~h}$ on d 18 to 20 , and machine milking was begun on $\mathrm{d} 21$ and continued for 14 wk (d 21 to 120). Goats were checked twice daily (after milking and when they returned from the pasture) for $7 \mathrm{wk}$ for estrual behavior (tail wagging, mounting, vulval swelling and redness, vaginal mucous discharge, and bleating) caused by the hormonal treatment.

Hormones and RES were supplied by Sigma-Aldrich (Sigma-Aldrich Química, Barcelona, Spain). Estradiol$17 \beta$, progesterone, and dexamethasone were dissolved in absolute ethanol to give concentrations of 20,50 , and $10 \mathrm{~g} / \mathrm{L}$, respectively. Solutions were protected from light and stored at room temperature (estradiol and progesterone) or at $4^{\circ} \mathrm{C}$ (dexamethasone). The RES solution was prepared just before injection by dissolving $10 \mathrm{mg}$ of RES in $0.5 \mathrm{~mL}$ of glacial acetic acid and was brought to a volume of $10 \mathrm{~mL}$ with sterilized distilled water.

Goats grazed for $6 \mathrm{~h}$ daily and were fed indoors with dehydrated ryegrass hay ad libitum ( $12 \% \mathrm{CP}$; as fed), $0.6 \mathrm{~kg}$ of commercial concentrate $\left(6.4 \mathrm{MJ}\right.$ of $\mathrm{NE}_{\mathrm{L}} / \mathrm{kg}$ and $16 \% \mathrm{CP}$; as fed), and $0.5 \mathrm{~kg}$ of alfalfa pellets (17\% CP; as fed). Goats were milked once daily at $0900 \mathrm{~h}$ in a double 12-stall parallel milking parlor (Westfalia-Separator Ibérica, Granollers, Spain) with recording jars (2 $\mathrm{L} \pm 5 \%)$ and a low milk pipeline. The milking machine was set at a vacuum pressure of $42 \mathrm{kPa}$, a pulsation rate of 90 pulses $/ \mathrm{min}$, and a pulsation ratio of $66 \%$. The milking routine included machine milking, stripping before cluster removal, and teat dipping in an iodine solution (P3-cide plus, Henkel Hygiene, Barcelona, Spain).

Experimental nulliparous goats were mated in May jointly with contemporary herdmates when all were still lactating and were milked once daily. Mating started after natural estrus induction by the buck effect with a teaser male for $4 \mathrm{~d}$. The teaser male was then replaced by fertile males ( 1 buck per 20 goats). The mating period lasted for $70 \mathrm{~d}$.

\section{Sample Collection, Analyses, and Measurements}

Milk yield was recorded daily during the first $3 \mathrm{wk}$ of lactation and thereafter on 2 consecutive days weekly 
until wk 14 of lactation. Milk composition was evaluated daily during wk 1 , weekly from wk 2 to 8 , and every 2 wk from wk 10 to 14 . A milk sample of approximately $100 \mathrm{~mL}$ was collected and preserved with an antimicrobial tablet (Bronopol, Broad Spectrum Microtabs II, D\&F Control Systems Inc., San Ramon, CA) at $4^{\circ} \mathrm{C}$. Unhomogenized milk samples were analyzed with a near-infrared spectrometer (Foss NIRSystems 5000, Foss, Hillerød, Denmark) for contents of TS, fat, protein $(\mathrm{N} \times 6.38)$, true protein, and $\mathrm{CN}$ (Albanell et al., 2003). Whey protein was calculated by the difference between true protein and CN, and NPN was calculated by the difference between protein and true protein.

Udder morphology traits were measured $2 \mathrm{~d}$ before the hormonal treatment and $7 \mathrm{~h}$ after milking, at wk 2 and 12 of induced lactation (d 35 and 105, respectively), as described by Peris et al. (1999). The measured udder traits were teat length $(\mathrm{mm})$ from the teat base to the teat orifice; distance between teats $(\mathrm{cm})$, as the distance between the 2 teat orifices; udder depth $(\mathrm{cm})$, as the distance between the rear udder attachment and udder base; and udder volume $(\mathrm{mL})$, as measured in a bucket by water displacement.

\section{Statistical Analyses}

Data were analyzed by SAS PROC MIXED for repeated measurements (version 9.1; SAS Inst. Inc., Cary, $\mathrm{NC}$ ). The statistical mixed model contained the random effect of animal within treatment (RES vs. control); the fixed effects of treatment and week of lactation; the interaction between treatment and week of lactation; and the residual error. The random effect of udder half nested within animal was added to the model in the analysis of the teat length trait. Data on total milk yield during the experiment were analyzed by one-way ANOVA using PROC GLM with a model containing the effect of treatment and the residual error. Pearson's correlation coefficients were calculated between udder morphology traits.

\section{RESULTS AND DISCUSSION}

The doses of estradiol and progesterone used in the present study were similar to those previously used in goats (Chilliard et al., 1986) and ewes (Head et al., 1980; Kann, 1997), but were 5 times greater than those used in dairy cows (Smith and Schanbacher, 1973; Collier et al., 1977; Kensinger et al., 1979). Higher hormonal doses might be necessary in ewes and goats because these animals have greater concentrations of estradiol and progesterone during pregnancy than cows (Convey, 1974), especially if they carry multiple fetuses (Manalu et al., 1996). Yet the ratio between estradiol

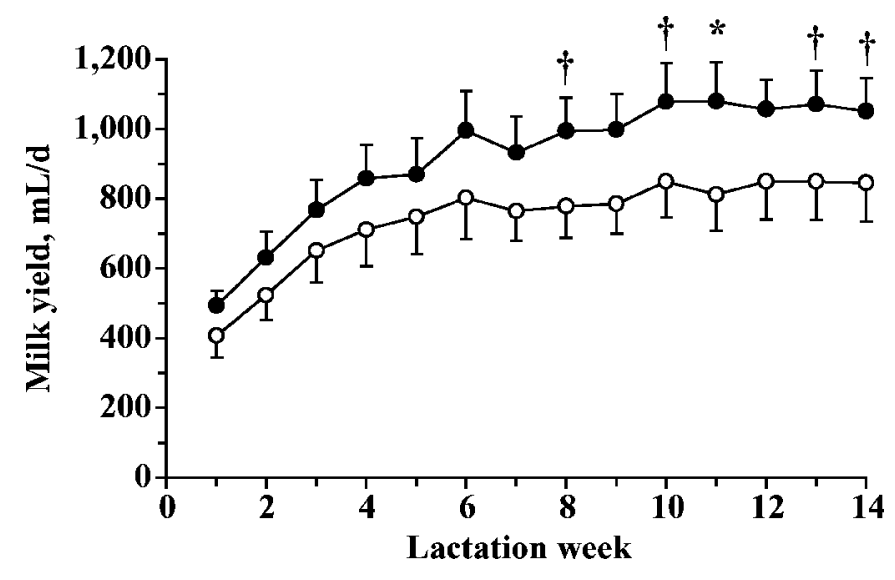

Figure 1. Milk yield of nulliparous dairy goats induced to lactate with $(\bullet ; \mathrm{n}=7)$ or without $(\bigcirc ; \mathrm{n}=7)$ reserpine. The asterisk $(*)$ and dagger $(\dagger)$ indicate that differences between the control and reserpinetreated goats were significant at $P<0.05$ and $P<0.10$, respectively.

and progesterone (1:2.5) in our study was the same as the ratio used in ewes and cows.

The udders of 7 goats began to fill with mammary secretion at 14 of treatment ( $1 \mathrm{wk}$ before the beginning of milking). No signs of estrous behavior were observed during the 7-d injection of estradiol and progesterone, but estrus was observed in 2 goats at d 12 of treatment (14\%) and estrous behavior gradually increased to $\mathrm{d} 17$, when 12 goats (86\%) displayed signs of estrous. Most goats had estrous signs to d 7 of lactation (d 28 of treatment) and some goats continued with estrous behavior until d 15 of lactation. Similar estrous behavior patterns were reported in dairy cows (Smith and Schanbacher, 1973), although the hormonal doses used in our goats were greater.

Two of the 7 goats treated with RES demonstrated slight shivering and drowsiness after the third injection. Reserpine acts by blocking the intraneuronal storage of neurotransmitters (dopamine, serotonin, and norepinephrine), both centrally and peripherally, and has a known $\beta$-adrenergic effect on the cerebral circulation of the goat, diminishing the vasoconstriction induced by nerve stimulation (Lluch et al., 1975). Nevertheless, by $48 \mathrm{~h}$ after RES injection these side effects were not observed.

\section{Milk Yield}

Milk yields for induced lactation are shown in Figure 1. The milk yield obtained at the first milking (d 21) was similar between control and RES-treated goats $(600 \pm$ 94 vs. $725 \pm 87 \mathrm{~mL} ; P=0.347)$. Similarly, daily milk yield did not vary $(P=0.253)$ between control $(659 \pm$ $81 \mathrm{~mL} / \mathrm{d})$ and RES-treated $(793 \pm 75 \mathrm{~mL} / \mathrm{d})$ goats from wk 1 to 7 of lactation (d 21 to 70). However, the differ- 
ence between the 2 groups tended to increase as lactation advanced, and from wk 8 to 14 (77 to $120 \mathrm{~d}$ ), REStreated goats $(1,052 \pm 94 \mathrm{~mL} / \mathrm{d})$ produced $28 \%$ more milk $(P<0.10)$ than did control goats $(825 \pm 100 \mathrm{~mL} /$ d). Week 8 of induced lactation (d 77) was in April, when the length of daylight was increasing rapidly. Increased milk yield with longer days has been reported for dairy goats (Salama et al., 2005) and may be due to an elevated secretion of PRL. Forsyth and Lee (1993) reported that goats treated with bromocriptine at parturition were unable to show the normal seasonal rise of PRL in summer, probably because of limited lactotrophs in the pituitary of the bromocriptine-treated goats. Because RES-treated goats should have had greater levels of PRL than control goats before the initiation of lactation, we speculated that RES-treated goats had more lactotrophs and responded better to the increased length of daylight than did control goats.

Peak milk yield in both groups was at wk 10 of lactation (d 90) and tended to differ $(P=0.084)$ between control $(850 \pm 96 \mathrm{~mL} / \mathrm{d})$ and RES-treated $(1,079 \pm 89 \mathrm{~mL} /$ d) goats. Goats from the same breed and herd peaked earlier at wk 3 to 4 after kidding (Salama et al., 2003). The delayed peak during induced lactation could be partially due to continued mammary proliferation after the start of lactation, as supported by the increase in udder volume during lactation (see discussion below). Similarly, peak milk yield during induced lactation was at wk 7 in ewes (Head et al., 1980) and wk 9 in dairy goats (Fowler et al., 1991). Fowler et al. (1991) reported that most udder development in goats induced to lactate took place after the cessation of steroid treatment, with a maximum achieved at wk 8 of induced lactation.

Using a peak milk yield of $\geq 0.5 \mathrm{~L} / \mathrm{d}$ as an arbitrary criterion for the success of lactation induction, we successfully induced $100 \%$ of goats to lactate. When this criterion was increased to $\geq 1 \mathrm{~L} / \mathrm{d}$, the success rate was $29 \%$ in control goats and $71 \%$ in RES-treated goats. Collier et al. (1977) reported a success rate, defined as a peak milk yield of $\geq 9 \mathrm{~kg} / \mathrm{d}$, of $55 \%$ in control cows and $100 \%$ in RES-treated cows. For all groups, correlations between milk yield at wk 1 and both peak milk yield $(\mathrm{r}=0.87)$ and lactation success rate, defined as a peak milk yield of $\geq 1 \mathrm{~L} / \mathrm{d}(\mathrm{r}=0.84)$, were significant $(P<$ $0.001)$. Peak milk yield values in control and REStreated goats were 49 and $60 \%$ of the peak milk yield values obtained after kidding in primiparous goats milked once daily from the same breed and herd (Salama et al., 2003).

Throughout the 14-wk lactation period (d 21 to 120), RES-treated goats $(922 \pm 85 \mathrm{~mL} / \mathrm{d})$ produced $24 \%$ greater daily milk yield than did control goats $(742 \pm$ $92 \mathrm{~mL} / \mathrm{d})$, but this difference was not significant $(P=$ 0.178 ), probably as a consequence of the high variability commonly observed among animals in their response to the hormonal treatment. Total milk yields during $100 \mathrm{~d}$ of milking were $73 \pm 9$ and $91 \pm 9 \mathrm{~L}$ in control and RES-treated goats, respectively $(P=0.202)$.

\section{Milk Composition}

Milk composition on the first day of lactation was similar between control and RES-treated goats (Figure 2) and averaged $17.0 \% \mathrm{TS}, 5.66 \%$ fat, $6.61 \%$ protein, $3.96 \% \mathrm{CN}, 2.62 \%$ whey protein, and $0.33 \%$ NPN. The whey protein, most of which is Ig, was low in first-day milk and represented only $40 \%$ of total milk protein. Caja et al. (2006) reported that whey protein accounted for $72 \%$ of total protein in the normal colostrum of dairy goats from the same breed and under similar conditions. The first milk obtained from goats on d 21 did not fully mimic normal colostrum (Caja et al., 2006). Smith et al. (1971) obtained a fluid nearly identical to colostrum on d 17 of treatment. Winger et al. (1995) showed that IgG concentration in cow milk peaked on d 15 of treatment and then decreased gradually, and that dexamethasone injections triggered sharp decreases in IgG concentrations in mammary secretions. In agreement with the lactation induction protocol followed, the first milking was done on $\mathrm{d} 21$ and dexamethasone was injected from d 18 to 20 , which may explain why this milk was different from normal colostrum.

The daily changes in milk composition during wk 1 of lactation are shown in Figure 2. No differences were detected between control and RES-treated goats on any day except the second day, when the milk of control goats contained greater $(P<0.05)$ percentages of fat, $\mathrm{CN}$, and TS. The milk fat, protein, CN, and TS percentages in both goat groups were high during the first 2 $\mathrm{d}$ of lactation, then decreased by d $3(P<0.05)$ to standard milk values and remained constant thereafter (Figure 2).

Throughout the experimental period, the milk contents of fat, protein, CN, and whey protein were similar between control and RES-treated goats (Table 1). The milk of control goats contained a greater $(P<0.05)$ percentage of NPN than did the milk of RES-treated goats. If the PRL concentration in the blood really differed between the 2 groups because of different responses to increased daylight, as previously indicated, differences in milk NPN between groups may be explained. The level of PRL may affect $\mathrm{N}$ metabolism in the body, because Brinklow and Forbes (1983) reported increased $\mathrm{N}$ retention in sheep when PRL was infused.

In our results, the $\mathrm{CN}$ :protein ratio was similar between groups and averaged $66 \%$. This value is lower than normal values reported in the milk of dairy goats 

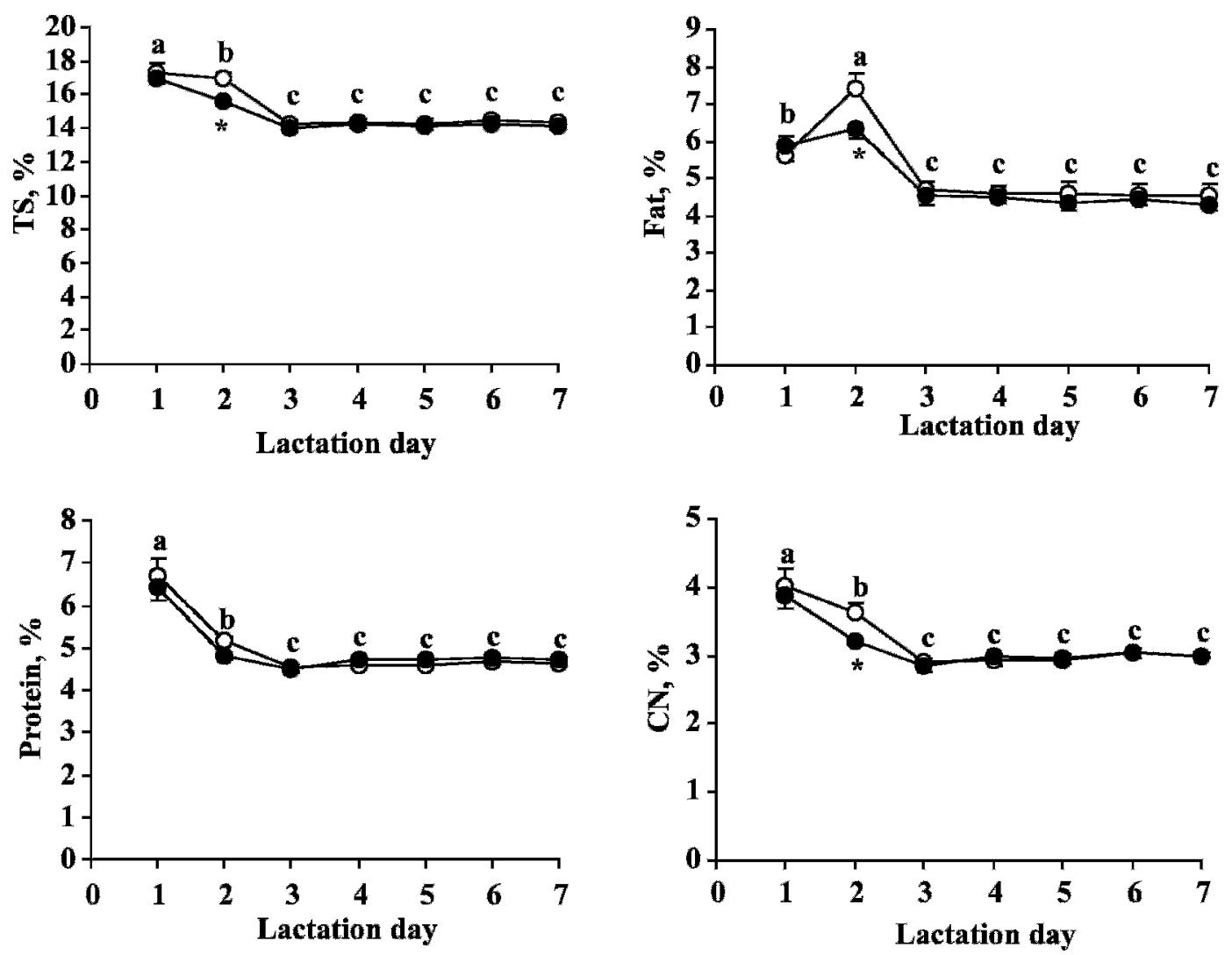

Figure 2. Milk composition changes during the first week of lactation in nulliparous dairy goats induced to lactate with $(P ; \mathrm{n}=7)$ or without $(O ; \mathrm{n}=7)$ reserpine. ${ }^{\mathrm{a}-\mathrm{c}}$ Means with different letters across days in goats treated with or without reserpine differ $(P<0.05)$. An asterisk $(*)$ indicates a difference $(P<0.05)$ between control and reserpine-treated goats.

from the same breed and herd, which ranged between 73 and $76 \%$ (Salama et al., 2003).

\section{Udder Morphology}

Teat length was small in the virgin goats before treatment, but this increased more in control goats than in RES-treated goats from $\mathrm{d}-2$ to $35(39.7 \% ; P<0.05)$ because of the hormonal challenge of lactation induc-

Table 1. Least squares means of average milk composition (d 21 to 120) in nulliparous dairy goats induced to lactate with or without reserpine

\begin{tabular}{lcccr}
\hline $\begin{array}{l}\text { Milk } \\
\text { component, \% }\end{array}$ & $\begin{array}{c}\text { Control } \\
(\mathrm{n}=7)\end{array}$ & $\begin{array}{c}\text { Reserpine } \\
(\mathrm{n}=7)\end{array}$ & $\mathrm{SED}^{1}$ & $P$-value \\
\hline TS & 13.9 & 13.6 & 0.2 & 0.158 \\
Fat & 4.62 & 4.36 & 0.24 & 0.338 \\
Protein & 4.29 & 4.21 & 0.16 & 0.639 \\
CN & 2.83 & 2.74 & 0.09 & 0.327 \\
CN, \% of protein & 66.4 & 65.4 & 1.3 & 0.462 \\
Whey protein & 1.46 & 1.47 & 0.08 & 0.900 \\
NPN & 0.48 & 0.41 & 0.02 & 0.016 \\
\hline
\end{tabular}

${ }^{1}$ Standard error of the difference. tion and remained constant thereafter (Table 2). Lammers et al. (1999) reported that estrogen implants in prepubertal dairy heifers increased teat length during the treatment period, but the effect was reversed posttreatment such that teat length was reduced by $30 \%$. The effects of estrogen on teat growth, which is responsible for ductal growth in the mammary gland, were modified in our case by the action of PRL in the REStreated goats; thus, teat growth stabilized during mammogenesis and increased during lactation (from d 35 to 105). This effect has not been described previously.

The distance between teats increased similarly for the control and RES-treated groups during the experiment, averaging $123 \%(P<0.01)$ during mammogenesis and $9 \%(P=0.448)$ during lactation (Table 2$)$. We were unable to measure udder volume or udder depth before the hormonal treatment $(\mathrm{d}-2)$ because virgin goats had no apparently visible udder. At wk 2 of induced lactation (d 35), there were no differences between the control and RES-treated groups in volume and depth of the udder, which averaged $768 \pm 70 \mathrm{~mL}$ and $14.2 \pm$ $0.6 \mathrm{~cm}$, respectively. There were no differences $(P=$ 
Table 2. Least squares means of udder morphology traits in nulliparous dairy goats induced to lactate with or without reserpine

\begin{tabular}{|c|c|c|c|c|}
\hline Item & $\begin{array}{l}\text { Control } \\
(\mathrm{n}=7)\end{array}$ & $\begin{array}{l}\text { Reserpine } \\
\quad(\mathrm{n}=7)\end{array}$ & $\mathrm{SED}^{1}$ & $P$-value \\
\hline \multicolumn{5}{|l|}{ Teat length, mm } \\
\hline Pretreatment, wk -4 & $24.7^{\mathrm{b}}$ & $24.4^{\mathrm{b}}$ & 1.5 & 0.857 \\
\hline Lactation, wk 2 & $34.5^{\mathrm{a}}$ & $26.0^{\mathrm{b}}$ & 3.3 & 0.017 \\
\hline Lactation, wk 12 & $33.2^{\mathrm{a}}$ & $29.0^{\mathrm{a}}$ & 4.2 & 0.324 \\
\hline \multicolumn{5}{|c|}{ Distance between teats, $\mathrm{cm}$} \\
\hline Pretreatment, wk -4 & $6.3^{\mathrm{c}}$ & $5.9^{\mathrm{c}}$ & 0.7 & 0.558 \\
\hline Lactation, wk 2 & $13.5^{\mathrm{b}}$ & $13.7^{\mathrm{b}}$ & 0.7 & 0.800 \\
\hline Lactation, wk 12 & $15.0^{\mathrm{a}}$ & $14.6^{\mathrm{a}}$ & 0.7 & 0.622 \\
\hline \multicolumn{5}{|l|}{ Udder depth, cm } \\
\hline Pretreatment, wk -4 & 0 & 0 & - & - \\
\hline Lactation, wk 2 & $14.1^{\mathrm{b}}$ & $14.3^{\mathrm{b}}$ & 0.9 & 0.817 \\
\hline Lactation, wk 12 & $16.7^{\mathrm{a}}$ & $17.1^{\mathrm{a}}$ & 0.9 & 0.648 \\
\hline \multicolumn{5}{|l|}{ Udder volume, $\mathrm{mL}$} \\
\hline Pretreatment, wk -4 & 0 & 0 & - & - \\
\hline Lactation, wk 2 & $784^{\mathrm{b}}$ & $751^{\mathrm{b}}$ & 96 & 0.732 \\
\hline Lactation, wk 12 & $1,035^{\mathrm{a}}$ & $1,119^{\mathrm{a}}$ & 96 & 0.398 \\
\hline
\end{tabular}

$0.107)$ in milk yield between the control $(850 \pm 96 \mathrm{~mL} /$ d) and RES-treated $(1,057 \pm 90 \mathrm{~mL} / \mathrm{d})$ goats at wk 12 , and no differences were detected in udder volume or udder depth.

From wk 2 to 12 , milk yield in both groups increased $(P<0.01)$ by $67 \%$, whereas udder volume increased $(P$ $<0.01$ ) by only $41 \%$. This may indicate that, in addition to mammary growth, mammary differentiation is responsible for increased milk yield during the induced lactation. Fleming et al. (1986) biopsied cows induced into lactation at $\mathrm{d} 0,14$, and 130 of lactation and found increased mammary differentiation from d 0 to 130 . Moreover, Chilliard et al. (1986) reported a greater RNA:DNA ratio in the mammary glands of goats induced into lactation compared with normally lactating goats at wk 18 of lactation.

Milk yield correlated positively with udder volume ( $\mathrm{r}=0.605, P<0.05 ; \mathrm{r}=0.767, P<0.01)$ and udder depth (r $=0.703, P<0.01 ; \mathrm{r}=0.751, P<0.01)$ at wk 2 and 12 , as previously reported in dairy goats during normal lactation (Peris et al., 1999). The distance between teats was not correlated with milk yield at wk 2 (d 35) or wk 12 (d 105). Udder depth and udder volume were correlated at both 2 and 12 wk $(\mathrm{r}=0.718 ; P<0.01)$. Udder depth was correlated with the distance between teats at 12 wk $(\mathrm{r}=0.557 ; P<0.05)$. Teat length was not correlated with milk yield or with any other udder morphology traits.

\section{Fertility}

Of the 14 experimental goats, only 3 (1 RES-treated and 2 control goats) became pregnant after mating in
May (21.4\%). The low fertility observed was not attributed to the male used for insemination because the same buck had mated 17 herdmates, and 14 of them had kidded (82.4\%). This result shows a negative side effect of the hormonal treatment on the reproduction of nulliparous goats.

The fertility obtained was much lower than the $56 \%$ reported by Collier et al. (1975) in dairy cows after lactation induction. High fertility (93\%) was observed (Magliaro et al., 2004) in dairy cows induced to lactate with lower doses of estradiol $(0.075 \mathrm{mg} / \mathrm{kg}$ of BW) than those used by Smith and Schanbacher (1973), although those cows had a history of reproductive problems. This may support the hypothesis that high doses of estradiol, as used in our study, may result in elevated residual estrogen and reduced fertility.

\section{CONCLUSIONS}

The 7-d hormonal protocol used was efficient to induce lactation in nulliparous goats and milk yield was marginally improved by using RES as a PRL stimulator. Nevertheless, the milk yield was only one-half that obtained after normal kidding in primiparous goats, indicating that induction protocols should be improved before practical use in goats. Moreover, the reduced fertility observed after the lactation induction treatment suggests the need for a substantial reduction of estrogen doses. Currently, this technique cannot be recommended for dairy goats.

\section{ACKNOWLEDGMENTS}

The authors are grateful to Ramón Costa and the team of the Servei de Granges i Camps Experimentals of the Universitat Autònoma de Barcelona for the care of the animals and to Nic Aldam for reviewing the manuscript.

\section{REFERENCES}

Albanell, E., G. Caja, X. Such, M. Rovai, A. A. K. Salama, and R. Casals. 2003. Determination of fat, protein, casein, total solids, and somatic cell count in goat's milk by near-infrared reflectance spectroscopy. J. AOAC 86:746-752.

Brinklow, B. R., and J. M. Forbes. 1983. Prolactin infusion causes increased nitrogen retention in lambs in continuous darkness. Proc. 79th Mtg. Br. Soc. Anim. Prod. 42:38A.

Byatt, J. C., R. H. Sorbet, P. J. Eppard, T. L. Curran, D. F. Curran, and R. J. Collier. 1997. The effect of recombinant bovine placental lactogen on induced lactation in dairy heifers. J. Dairy Sci. 80:496-503.

Caja, G., A. A. K. Salama, and X. Such. 2006. Omitting the dry-off period negatively affects colostrum and milk yield in dairy goats. J. Dairy Sci. 89:4220-4228.

Chakriyarat, S., H. H. Head, W. W. Thatcher, F. C. Neal, and C. J. Wilcox. 1978. Induction of lactation: Lactational, physiological, and hormonal responses in the bovine. J. Dairy Sci. 61:1715-1724. 
Chilliard, Y., C. Delouis, M. C. Smith, D. Sauvant, and P. MorandFehr. 1986. Mammary metabolism in the goat during normal or hormonally-induced lactation. Reprod. Nutr. Dev. 26:607-615.

Collier, R. J., D. E. Bauman, and R. L. Hays. 1975. Milk production and reproductive performance of cows hormonally induced into lactation. J. Dairy Sci. 58:1524-1527.

Collier, R. J., D. E. Bauman, and R. L. Hays. 1977. Effect of reserpine on milk production and serum prolactin of cows hormonally induced into lactation. J. Dairy Sci. 60:896-901.

Convey, E. M. 1974. Serum hormone concentrations in ruminants during mammary growth, lactogenesis, and lactation: A review. J. Dairy Sci. 57:905-917.

Cowie, A. T., C. P. Cox, S. J. Folley, Z. D. Hosking, M. Naito, and J. S. Tindal. 1965. The effects of the duration of treatments with estrogen and progesterone on the hormonal induction of mammary growth and lactation in the goat. J. Endocrinol. 32:129-139.

Davis, A. J., I. R. Fleet, J. A. Goode, M. H. Hamon, F. M. M. Walker, and M. Peaker. 1979. Changes in mammary function at the onset of lactation in the goat: Correlation with hormonal changes. J. Physiol. 288:33-44.

Erb, R. E., E. L. Monk, T. A. Mollett, P. V. Malven, and C. J. Callahan. 1976. Estrogen, progesterone, prolactin and other changes associated with bovine lactation induced with estradiol-17 $\beta$ and progesterone. J. Anim. Sci. 42:644-654.

Fleming, J. R., H. H. Head, K. C. Bachman, H. N. Becker, and C. J. Wilcox. 1986. Induction of lactation: Histological and biochemical development of mammary tissue and milk yields of cows injected with estradiol-17 $\beta$ and progesterone for 21 days. J. Dairy Sci. 69:3008-3021.

Forsyth, I. A., and P. D. Lee. 1993. Bromocriptine treatment of periparturient goats: Long-term suppression of prolactin and lack of effects on lactation. J. Dairy Res. 60:307-317.

Fowler, P. A., C. H. Knight, and M. A. Foster. 1991. In-vivo magnetic resonance imaging studies of mammogenesis in non-pregnant goats treated with exogenous steroids. J. Dairy Res. 58:151-157.

Hart, I. C., and S. V. Morant. 1980. Roles of prolactin, growth hormone, insulin and thyroxine in steroid-induced lactation in goats. J. Endocrinol. 84:343-351.

Head, H. H., C. Delouis, M. Terqui, G. Kann, and J. Djiane. 1980. Effects of various hormone treatments on induction of lactation in the ewe. J. Anim. Sci. 50:706-712.

Kann, G. 1997. Evidence for a mammogenic role of growth hormone in ewes: Effects of growth hormone-releasing factor during artificial induction of lactation. J. Anim. Sci. 75:2541-2549.
Kensinger, R. S., D. E. Bauman, and R. J. Collier. 1979. Season and treatment effects on serum prolactin and milk yield during induced lactation. J. Dairy Sci. 62:1880-1888.

Lammers, B. P., A. J. Heinrichs, and R. S. Kensinger. 1999. The effects of accelerated growth rates and estrogen implants in prepubertal Holstein heifers on estimates of mammary development and subsequent reproduction and milk production. J. Dairy Sci. 82:1753-1764.

Lluch, S., B. Gómez, E. Alborch, and P. R. Urquilla. 1975. Adrenergic mechanisms in cerebral circulation of the goat. Am. J. Physiol. 228:985-989.

Lukas, J. M., W. J. Weber, R. J. Collier, J. L. Vicini, M. F. McGrath, and B. A. Crooker. 2003. Intramammary infusion of prostaglandin $\mathrm{E}_{2}(\mathrm{PGE})$ increases mammary development and milk yield of cows induced to lactate. J. Dairy Sci. 86(Suppl. 1):189. (Abstr.)

Magliaro, A. L., R. S. Kensinger, S. A. Ford, M. L. O'Connor, L. D. Muller, and R. Graboski. 2004. Induced lactation in nonpregnant cows: Profitability and response to bovine somatotropin. J. Dairy Sci. 87:3290-3297.

Manalu, W., M. Y. Sumaryadi, and N. Kusumorini. 1996. Effect of fetal number on the concentrations of circulating maternal serum progesterone and estradiol of does during late pregnancy. Small Rumin. Res. 23:117-124.

Peris, S., G. Caja, and X. Such. 1999. Relationships between udder and milking traits in Murciano-Granadina dairy goats. Small Rumin. Res. 33:171-179.

Salama, A. A. K., G. Caja, X. Such, R. Casals, and E. Albanell. 2005. Effect of pregnancy and extended lactation on milk production in dairy goats milked once daily. J. Dairy Sci. 88:3894-3904.

Salama, A. A. K., X. Such, G. Caja, M. Rovai, R. Casals, E. Albanell, M. P. Marin, and A. Marti. 2003. Effects of once versus twice daily milking throughout lactation on milk yield and milk composition in dairy goats. J. Dairy Sci. 86:1673-1680.

Smith, K. L., L. A. Muir, L. C. Ferguson, and H. R. Conrad. 1971. Selective transport of IgGI into the mammary gland: Role of estrogen and progesterone. J. Dairy Sci. 54:1886-1894.

Smith, K. L., and F. L. Schanbacher. 1973. Hormone induced lactation in the bovine. I. Lactational performance following injections of $17 \beta$ estradiol and progesterone. J. Dairy Sci. 56:738-743.

Winger, K., C. C. Gay, and T. E. Besser. 1995. Immunoglobulin $\mathrm{G}_{1}$ transfer into induced mammary secretions: The effect of dexamethasone. J. Dairy Sci. 78:1306-1309. 